\title{
MOOC-based Flipped Classroom of College English: Reconstruction of an Efficient Model of Teaching and Learning*
}

\author{
Mingyu Sun \\ School of Foreign Studies \\ Shandong Technology and Business University \\ Yantai, China
}

\author{
Songqing Li \\ School of Foreign Studies \\ Shandong Technology and Business University \\ Yantai, China
}

\begin{abstract}
Chinese College English learning has long been overwhelmed by the direction of traditional-classroom teaching. This paper first discussed the problems in traditional English-classroom, and then improved College English classroom by integrating Massive Open Online Course (MOOC), mobile learning and social communication into classroom teaching and learning practice. The flipped College English classroom based on MOOC functions as productive model of teaching and learning which has advanced English learning by furnishing online resources, group cooperation, and after-class analysis and reflection.
\end{abstract}

Keywords-college English; MOOC; flipped classroom; model of teaching and learning

\section{INTRODUCTION}

"The reform of College English teaching has been implemented since 2003, which has gone through ten years. Its content is to attach importance to the training of listening and speaking ability, to establish a teaching model based on computer and classroom, to promote the combination of formative assessment and finality assessment, and to develop students' autonomous learning ability. (Wang Shouren, 2013)" With in-depth educational reform in China, it began to dawn on increasingly more teachers and educators that it is not sufficient to focus on researching what to teach and how to teach, so the researchers pay more attention to how to facilitate the efficient learning through effective teaching. However, attention has to be drawn to the plight in today's college English classroom learning in China.

In China, English is a non-working language and Chinese lacks the occasions to use English, which makes the teaching and learning in English class turn to be particularly significant for Chinese learners. But there remain three predicaments in College English teaching and learning: First, there exist a large number of College English learners in an English class, and traditional-classroom teaching cannot fully realize individualized teaching and support individuality. Secondly, the negative impact of examoriented teaching on language learning, which distorts the

*Shandong Social Science Planning Research Project, Design of Individualized Teaching Objectives in College English Classroom Based on Information Technology, Approval Number: 14CWXJ50 essence of language learning. Third, the teaching and learning in a college English classroom is mainly based on a teacher's lecturing, with a single function, therefore, it is impossible to form an effective combination of classroom teaching with extracurricular learning. (Shu Dingfang, 2014). In broad sense, there are two kinds of problems in college English, which are the teaching and learning in college English classroom. For many teachers, when teaching college English usually in larger classes which may be one of proximate reasons why college English class is inefficient in China, teachers tend to use several simple traditional teaching methods, such as vocabulary explanation, grammatical teaching, and sentence pattern practice which has greatly hindered the progress of modern teaching and such cramming teaching has gradually weakened the students' interest in learning English. Moreover, some college English teachers in China have vague classroom teaching objectives and lag behind in theoretical research. Meanwhile, for quite large number of college students, they are addicted to their mobile phones, and are always absentminded in class, and do not finish homework after class, and sometimes some of them even skip classes. English learning autonomy has not been cultivated and formed during high school education, and hence it is not an easy job for them to form the consciousness of English autonomous learning and have strong ability of autonomous learning. Based on the analysis of these problems, this paper puts forward the topic about construction of an efficient model of teaching and learning that need to be focused and studied.

\section{Problems ABout College English in ChinA}

\section{A. Low-effective Teacher-centered Teaching Model}

In traditional classroom, teacher-centered teaching model in college English teaching restricts and suppresses English learners' enthusiasm and desire in learning and speaking English, which leads to low teaching efficiency. Although college English teachers are gradually accepting studentcentered teaching model in their teaching and studentcentered teaching method is also reflected in the teacher's educational philosophy and teaching practice, there is a gap 
between teachers' learner-centered belief and teachers' teaching practice in College English classroom.

On the other hand, at the level of teaching organization, College English credits are reduced and class-hours are decreasing. (Wang Shouren \&Wang Haixiao, 2011). Classroom time is becoming limited, which must not provide enough input materials and output practice if teachers insist on traditional teaching.

\section{B. Disconnection between Classroom Teaching and After- class Learning}

Wang Shouren and Wang Haixiao find that although the concept of formative assessment has been generally accepted, how to assess college students' autonomous learning in the formative assessment system which needs a long way to go. (Wang Shouren \& Wang Haixiao, 2011). College English teachers have developed the belief that college students need to learn autonomously after class, however, classroom teaching hasn't yet been connected effectively with afterclass learning, which could be embodied in two aspects: on the one hand, in terms of the content of extracurricular learning, there is lack of correlation between the content of classroom teaching and extracurricular learning. Teachers need a lot of study and thinking about how to connect their classroom teaching with their students' extracurricular learning. Moreover, insufficient time and chances are provided to students in order to present what they have learned after class. And on the other hand, teachers haven't offered enough effective advices and guidance to autonomous learners in classroom. In traditional classroom teaching, due to the lack of effective records, supervision, measurement and evaluation of English learning process and learning results (Xu Jinfen, 2015), teachers have difficulty in solving the problem of how to ensure that every student can finish their autonomous learning carefully and of how to ensure that the after-class learning can promote their study.

\section{Insufficient Teacher-student and Student-student Interaction}

The interaction between teachers and students is the most important interaction that can affect students. In class, it mainly exists in questions and responses, demands and reactions, evaluation and feedback in classroom teaching. Through the reform of College English teaching, teachers' consciousness of interactive teaching has been improved in college English classroom. However, there exist the following problems, for instance, teachers tend to save classroom time by interacting with all students, which ignores the interaction with an individual student. In terms of group interaction, during the discussion for students' groups, teachers may merely walk between groups, and seldom go to the students to have an exchange with learners in groups. And if teachers let students have a discussion, some students take the opportunity to do their own things, and do not participate in their discussion, affecting the effectiveness of classroom interaction.

Teaching process is a whole. So we must attach importance to the combination of classroom interaction and extracurricular one. The following will discuss the problems existing in after-class interaction. At first, both teachers and students don't put enough emphasis on extracurricular teaching activities and their interaction consciousness needs to be improved. Secondly, in the extracurricular teaching, teachers often arrange a unified learning task for all the students and learning activities is monotonous and the way to finish tasks is also single, which may lead to a single form of interaction between teachers and students. Thirdly, as for the extracurricular teaching, the teacher pays not enough attention to check students' extracurricular tasks, and the teacher provides not sufficient guidance to students' problems in the course of after-class learning, which leads to less interaction between teachers and students, thus reducing the opportunities of interactive discussion between teachers and students and affecting the effective feedback of the information between teachers and students.

\section{THE MOOC-BASED FLIPPED CLASSROOM OF COLLEGE ENGLISH}

\section{A. The MOOC-based College English}

Educational technology is to promote learning through research and application of information technology. The goal of educational technology is to promote human learning by means of technology. (Gao Liming, Zhu Benjun, 2005) The Association for Educational Communications and Technology (AECT) defined educational technology as "the study and ethical practice of facilitating learning and improving performance by creating, using and managing appropriate technological processes and resources". (Richey, 2008) Its ultimate goal is to improve the effectiveness of education and learning. MOOC (Massive Open Online Course) has brought the new type of Digital Information Age with its excellent teaching resources. In addition to traditional course materials such as filmed lectures, readings, and problem sets, many MOOCs provide interactive user forums to support community interactions among students, professors, and teaching assistants.

The Requirements for the Teaching of College English Courses (2007) point out that "College English is a teaching system based on foreign language teaching theory, with the main content of English language knowledge and application skills, intercultural communication and learning strategies, together with various teaching modes and means." In summary, College English Course focuses on three aspects: (1) English language knowledge, such as vocabulary, grammar, etc.; (2) language application skills, including listening, speaking, reading, writing, translation, etc.; (3) cross-cultural communication and learning strategies. To achieve the goal of College English Courses, it is inseparable from the deep reform of teaching mode based on MOOC. With an obvious advantage over the traditional class, the teaching in MOOC micro video is usually repeatedly polished, so that its language knowledge is explained more efficiently than an individual teacher's input in class teaching. And students can selectively watch and adapt to their personalized learning by practicing their own weak language skills such as listening and speaking. Furthermore, MOOC 
videos with multimodal stimuli are better than traditional reading textbooks, which help students understand cultures better through visualized cross-cultural communication. In all these effort, students can study, practice and improve their learning strategies as well. Hence, MOOC can maximize the effectiveness of input.

On the other hand, classroom time is so limited that teachers cannot use traditional teaching methods to cover the input and output in students' learning process. MOOC-based teaching mode is in line with the practical needs of College English teaching. After class, learners can learn knowledge points autonomously based on MOOC videos. Therefore, the MOOC learning and classroom teaching must be closely integrated and indispensable. Classroom teaching should focus on how to output effectively, and MOOC learning should focus on how to input effectively.

\section{B. The Flipped Classroom of College English}

The flipped classroom intentionally shifts instruction to a learner-centered model in which class time explores topics in greater depth and creates meaningful learning opportunities, while educational technologies such as online videos are used to 'deliver content' outside of the classroom. A "flipped classroom" model, as one of the new instructional strategy, is a type of blended learning which reverses the traditional way of internalizing knowledge, delivers knowledge online or outside of classroom, but internalizes knowledge in the classroom. It moves activities, including those that may have traditionally been considered homework, into the classroom.

Given the low-effective teacher-centered teaching model - the problem of College English mentioned above, a flipped classroom of College English just facilitate teachers form the consciousness of "students-centered" teaching model by English learners watching online videos and taking part in online discussions after class. By this way, it can improve the low efficiency of traditional "teacher-centered" teaching model. At the same time, the problem, above mentioned, the disconnection between classroom teaching and after-class learning can be well-solved and improved. Students apply what they learn online before class into analysis of the questions which need their deeper thinking, and finally collaborate in key points or challenging problems in the classroom with the guidance of a teacher. Before class, learners study independently and autonomously with the help of information technology. In class, the exchange between students and teachers may cultivate the students' thinking ability to use knowledge flexibly. And the classroom is the place where students practice language. As to the interaction problem, the flipped classroom model subverts the teaching process, and the teaching combines "self-learning online before class" with "internalizing knowledge through the interaction of teachers and students and interaction between students and students in the teacher's class as a tutor". This approach not only enhances the interaction between teachers and students, but also accords with the actual situation of College English Teaching in large classes.

\section{RECONSTRUCTION OF AN EFFICIENT MODEL OF TEACHING AND LEARNING}

The traditional teaching structure in classroom needs to be reconstructed. Teachers, students and teaching materials constitute the teaching structure in English classroom. In the teaching model of traditional classroom, teachers are the center of classroom teaching in College English class. Teachers usually use a number of practices, such as sentence-making, translation, interpretation, short answer in English classroom. Students usually learn English passively in class. In this traditional model, teaching is explicit, and learning is implicit. Change the structure of traditional classroom teaching, which need to turn teaching and learning over the roles and change their relationship in traditional classroom, changing "learning" as dominance and as center, establishing "teaching and learning" as an efficient model, and implementing effective teaching through learners' active learning.

In view of the problems and shortcomings of traditional classroom, the "Chinese University MOOC" platform, the social mode and mobile learning are introduced into the English learning process, based on the advantages of MOOC-based flipped classroom model. The following part will propose an efficient model of English teaching and learning, and such model is the reconstruction of traditional classroom teaching.

The MOOC-based flipped classroom in university English teaching may transfer language instruction to the "Chinese University MOOC" platform, which will save classroom time and space. Based on "Chinese University MOOC" platform, College English flipped class is designed in the following way. We take the "College English reading and writing" as an example, for it is one of the basic courses in the College English course system in our university. It aims at cultivating students' comprehensive ability of reading and writing and thinking ability, which requires a lot of practical activities.

Taking Unit Four of the textbook "New Horizon College English (Book I)" as an example, we design the task or project such as the report on "Premarital Agreement among the college students". To achieve this project, the three parts can be divided, that is, pre-classroom part is about preliminary learning with the help of peers; classroom part is about in-depth learning and presentation with the guidance of teachers; and post-classroom part is about reflection, each of which involved online activities and classroom activities respectively. (See Fig. 1) 


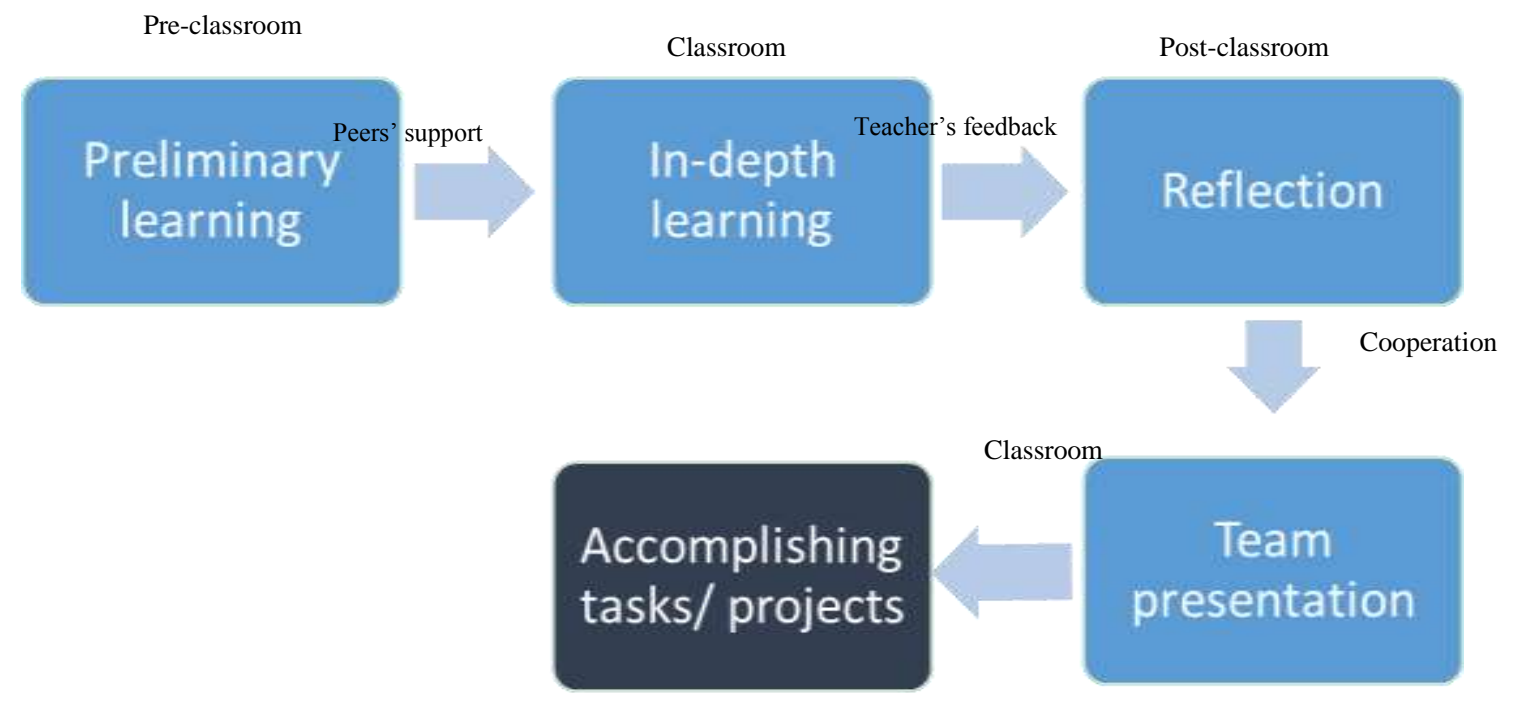

Fig. 1. The MOOC-based College English Flipped Classroom Model of Teaching and Learning.

Preliminary learning: students learn online materials about the premarital agreements in American culture and celebrity cases of the news reports, understand the theme of the background knowledge, design the campus questionnaire of the premarital agreement, implement the survey, and collect data. The online platform provides video with text explaining, language points and reflection questions, arouses students thinking, and prepares for classroom debates, and finally prepare to report the results of the survey in classroom. In the process of learning after class, teachers can be liberated to do more effective classroom teaching task by encouraging students to use mobile learning APP which can help teachers make records, monitor and analyze students' learning process, and facilitate a kind of fair and competitive learning. The mobile learning application makes teachers' classroom management more efficient. Every student's task can be recorded. It is convenient for teachers to manage and evaluate the classroom tasks or projects.

In-depth learning: the group will discuss and analyze the campus premarital agreement based on the survey results, and read two articles in the textbook independently. In class, the students are divided into two sides to debate on "whether our college students need a premarital agreement or not". In the debate process, in-depth analysis and thinking is being formed and presented. The classroom becomes the place to develop students' comprehensive ability to use the English language, to provide students with the opportunity to practice the language, and to guide the students to participate in online discussion. The teachers in flipped classroom pay more attention to how to promote effective learning. It is the core goal for teachers to create the situation to use English based on the subject, design the tasks and projects, make each student participate in those tasks and projects, and improve the English comprehensive ability by doing tasks.
Reflection: students reflect on the results of learning, write project reports on the basis of previous tasks, describe the existing problems on campus survey, analyze the problems in multiple angles, find out the reasons for the problems, and put forward solutions. Students may be suggested to set up an online learning community to participate in the process of communication and interaction with their peers, teachers, and teaching assistants, so thus each can mutually share their experience, resources, strategies and thoughts, explore topics, exchange ideas, ask questions, and answer questions. In such online interactive environment, new idea and new knowledge can be generated and consolidated, and the language can be promoted. The reflection and interaction enables language learning to be constructed in the online learning community.

\section{CONCLUSION}

It is not easy to make English teaching and learning effective. The bottleneck problem in traditional classroom is that traditional teaching has hindered effective learning. The flipped classroom under the MOOC environment is the organic integration of "online learning" and "classroom teaching". It is also a good interpretation of the application of modern information technology to promote teaching and learning. The MOOC flipped class in College English is a good choice in the reform of College English Teaching. Its purpose is to reconstruct the classroom teaching and make up for the shortcomings of the traditional classroom teaching, to reconstruct the students' English learning process, and to innovate the effective English learning model. And moreover, group interaction activities in online community enhance students' learning motivation, reduce their anxiety, promote their collaboration and communication, and MOOC-based flipped classroom may be an effective organizational form for classroom activities. 
With the development of information technology, more and more people pay attention to the issue of flipped classroom model. However, how to design and produce the online course of College English and how to combine the online courses with the traditional English class should be further explored and discussed in practice. The fundamental advantage of flipped classroom is not the application of technology, but also the improvement of the overall teaching model brought about by technological development. Only doing further research into College English courses, College English teaching and learning can have better performance in the future.

\section{REFERENCES}

[1] Wang Shouren. Adhere to the Scientific View of College English Teaching Reform [J]. Foreign Language World, June 2013 王守 仁. 坚持科学的大学英语教学改革 $[\mathrm{J}]$. 外语界, 2013 (6).

[2] Su Dingfang. Problems and Research topics about Teaching in Foreign Language Classroom [J]. Foreign Language Teaching and Research, March 2014 束定芳. 外语课堂教学中的问题与若干研 究课题 $[\mathrm{J}]$. 外语与外语教学, 2014(3).

[3] Cochran-Smith, M. \& S. Lytle. 1993. Inside/ outside Teacher Research and Knowledge [M]. New York: Teachers College Press.

[4] Wang Shouren, WangHaixiao. On the State of College English Teaching in China and Its Future Development $[\mathrm{J}]$. Foreign Language of China, May 2011 王守仁, 王海啸. 我国高校大学英 语教学现状调查及大学英语教学改革与发展方向 $[\mathrm{J}]$. 中国外 语, 2011(5).

[5] Han Jiying, WangJunju, ZhengXin. College English teachers goal orientations for teaching and their approaches to teaching: Characteristics and relationships [ $\mathrm{J}]$. Modern Foreign Languages, June 2017 韩佶颖, 王俊菊, 郑金金. 大学英语教师教 学目标取向与教学方式的特征及关系探究 [J] . 现代外语, 2017 ( 6)

[6] Xu Jinfen, Foreign Language Classroom Research: Retrospects and Prospects [J]. Sep. 92015 徐锦芬. 外语课堂研究: 回顾与展望 [J]. 当代外语研究 2015(9).

[7] Wu Kangning et al. Sociology of classroom teaching [M]. Nanjing: Nanjing Normal University Press, 1999. 吴康宁等, 课堂教学社会 学 [M] 南京: 南京师范大学出版社, 1999 .

[8] Gao Liming, Zhu Benjun. Effective learning under the Support of Technology [J]. Theoretical Study, May 2005 高利明, 朱本军. 技 术支持下的有效学习 $[\mathrm{J}]$. 理论探讨, 2005( 5).

[9] Hu Jiehui, Wu Zhongjie. An Empirical Study on the MOOC-based College English Flipped Classroom Instructional Model [J]. CAFLE, Nov. 2014 胡杰辉, 伍忠杰. 基于 MOOC 的大学英语翻转课堂教 学模式研究 [J]. 外语电化教学, 2014(11)

[10] Richey, R. C. Reflections on the 2008 AECT Definitions of the Field [J]. Technology Trends, 2008( 1).

[11] Higher Education Department of the Ministry of education. Requirements for College English Teaching [M]. Beijing: Foreign Language Teaching and Research Press, 2007. 教育部高等教育 司. 大学英语课程教学要求 $[\mathrm{M}]$. 北京: 外语教学与研究出版 社, 2007.

[12] Abeysekera, Lakmal, Phillip Dawson. Motivation and cognitive load in the flipped classroom: definition, rationale and a call for research [J]. Higher Education Research \& Development, 2015(1).

[13] Marco Ronchetti, Using video lectures to make teaching more interactive [J]. International Journal of Emerging Technologies in Learning, 2010 (6)

[14] Deng Di. A Review of the Application of the "Flipped Classroom" Model in College English Teaching [J]. Foreign Language World, No. 42016 邓笛. 翻转课堂模式在大学英语教学中的应用研究述评 $[\mathrm{J}]$. 外语界, $2016(4)$
[15] Enfield J. Looking at the impact of the flipped classroom model of instruction on undergraduate multimedia students at CSUN [J]. Tech Trends, 2013, 57( 6) : 14-27. 